\title{
PRELIMINARY GEOSITE ASSESSMENT MODEL (GAM) AND ITS APPLICATION ON FRUSKA GORA MOUNTAIN, POTENTIAL GEOTOURISM DESTINATION OF SERBIA
}

Miroslav D. Vujičić, Djordjije A. Vasiljević, Slobodan B. Marković, Thomas A. Hose, Tin Lukić, Olga Hadžić, Sava Janićević

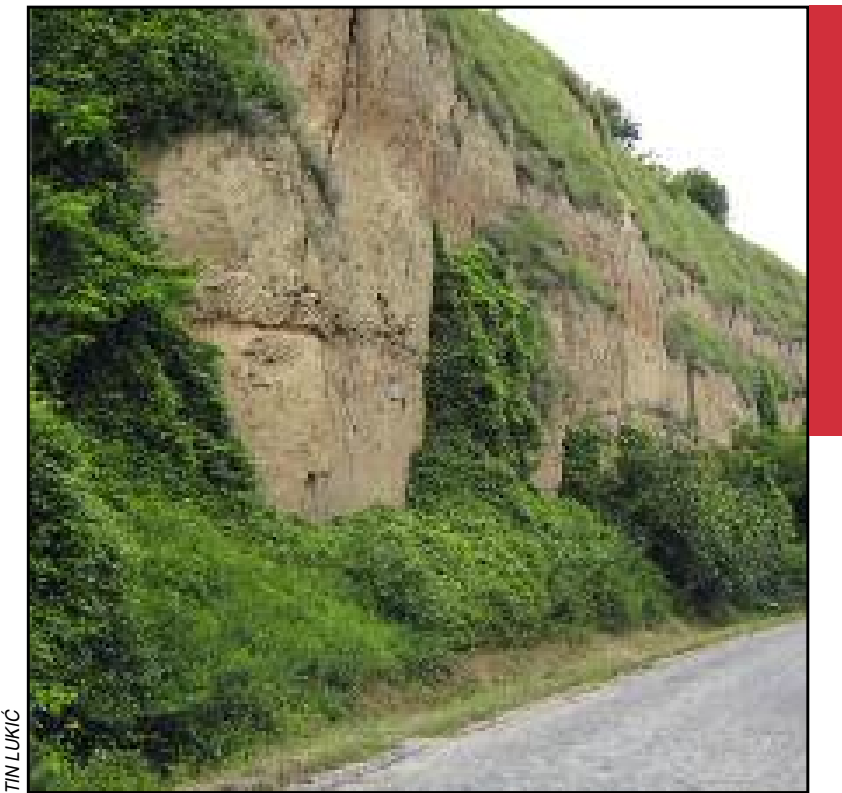

Loess profile "Surduk « in the gully between Novi Slankamen and Stari Slankamen villages - currently the only law protected loess exposure in Serbia with fossil palaeosols 


\title{
Preliminary geosite assessment model (gam) and its application on Fruška gora mountain, potential geotourism destination of Serbia
}

\author{
DOI: $10.3986 / A G S 51303$ \\ UDC: 913:338.483(497.11) \\ 338.483:55(497.11) \\ COBISS: 1.01
}

\begin{abstract}
This paper presents a preliminary geosite physical assessment model which has the potential to assist in the sustainable planning and management of natural heritage locations and their transformation into tourism destination. The methodology is based on several existing models and presented through two groups of values - main and additional, which are further divided into indicators and subindicators respectively. The resultant model is a graph that consists of nine fields, into which geosites can be classified as fitting into nine general areas of suitability for tourism in terms of their main (scientific/educational, aesthetic/scenic and protection as market appeal and conservation) and additional values (functional and tourism use as current stage of development). This could prove to be of great help to natural heritage protection and tourism managers, as they could assess the current state of a geosite and thence propose a future path for it.
\end{abstract}

KEY WORDS: geosites, assessment, geotourism, Fruška gora, Serbia

The article was submitted for publication on May 19, 2011.

ADDRESSES:

Miroslav D. Vujičić, M. Sc.

Department of Geography, Tourism and Hotel Management, Faculty of Sciences, University of Novi Sad Trg Dositeja Obradovića 3, 21000 Novi Sad, Serbia

E-mail: miroslav.vujicic@dgt.uns.ac.rs

Djordjije A. Vasiljević, M. Sc.

Department of Geography, Tourism and Hotel Management, Faculty of Sciences, University of Novi Sad Trg Dositeja Obradovića 3, 21000 Novi Sad, Serbia

E-mail: geotrends@dgt.uns.ac.rs

Slobodan B. Marković, Ph. D.

Department of Geography, Tourism and Hotel Management, Faculty of Sciences, University of Novi Sad Trg Dositeja Obradovića 3, 21000 Novi Sad, Serbia

E-mail: slobodan.markovic@dgt.uns.ac.rs

Thomas A. Hose, Ph. D.

School of Earth Sciences, University of Bristol, Wills Memorial Building, Queens Road, Bristol, BS8 1RJ, UK E-mail: gltah@bristol.ac.uk

Tin Lukić, M. Sc.

Department of Geography, Tourism and Hotel Management, Faculty of Sciences, University of Novi Sad Trg Dositeja Obradovića 3, 21000 Novi Sad, Serbia

E-mail: tin.lukic@dgt.uns.ac.rs

Olga Hadžić, Ph. D.

Department of Mathematics and Informatics, Faculty of Science, University of Novi Sad, Trg Dositeja Obradovića 2, 21000 Novi Sad, Serbia

E-mail: ohadzic@dmi.uns.ac.rs 


\section{Sava Janićević, Ph. D.}

Department of Mathematics and Informatics, Faculty of Science, University of Novi Sad, Trg Dositeja Obradovića 2, 21000 Novi Sad, Serbia

E-mail: sava.janicevic@dgt.uns.ac.rs

\section{Contents}

1 Introduction

Regional settings and geosites inventory $\quad 364$

3 Methodology

366

4 Application of GAM to Stari Slankamen loess geosite

5 Results and discussion

6 Conclusion

7 Acknowledgement

374

8 References 


\section{Introduction}

As tourists' expectations of quality experiences from the late twentieth century became more demanding, they were reflected in the expansion of their interest in and motivation to adopt new emerging forms of tourism such as special interest (Weiler and Hall 1992) and niche (Novelli 2005) tourism. Furthermore, the slightly earlier and concomitant rapid urbanization and other human-made activities that increasingly degraded the environment (see Fairbrother 1970 for discussion) influenced modern tourists to convert to sustainable and nature-friendly tourism activities commonly in aesthetic landscape settings, commonly identified as sustainable tourism (Page and Connell 2007) and ecotourism (Boo 1990). This indicates that the promotion of natural resources raises tourists' consciousness, not only about their importance and attractiveness, but also their vulnerability and thus conservation necessity. This conservation rationale underpins the geotourism concept as developed in Europe (Hose 1995) that also promotes tourism for both urban and, especially relevant to the model herein presented, rural destinations whilst promoting geoconservation (Hose 2007).

Besides living nature, flora and fauna, recent European leisure trends have shown heightened appreciation of non-living natural resources - geodiversity. This variety of abiotic natural resources is defined by Gray (2004) as »the range of soil, geomorphological and geological features«. The components of geodiversity that have scientific, educational, aesthetical and inspirational significance are considered to be determined as geoheritage (Dixon 1996; Erhartič 2010) and they are identified as having conservation significance (Gray 2004, Erikstad 2008). Conservation of the geoheritage (geoconservation) is a dynamic approach to the preservation and maintenance of geosites (Hose 2003) whose main purpose is to address concerns over their damage or destruction, whilst at the same time recognising the need to ensure through promotion and interpretation their availability and access (Hose 2005a) to a wider audience of casual as well as dedicated geotourists (Hose 2005b). This form of activity is underpinned by what has been defined from the 1990s as 'geotourism' which is focused on »the promotion of geologic and geomorphic sites for their scientific and societal value to ensure their conservation for future use by academics, tourists and casual recreationalists (Hose 2000, 2008). A recent geotourism model indicates the necessity to select and inventory geosites identified initially through geological and geomorphological research and evaluated against tourism infrastructure, to underpin its development.

In this context, as for every destination and its special places, before any planning at potential geotourism destinations, there should be a thorough assessment made to determine the condition and values of all the geosites of a destination. This assessment should give the clear picture of future activities regarding further development and management of geotourism at these sites. Thus, assessment should not only involve classification of sites, but offer suggestions for their protection, promotion and monitoring (Pereira et al. 2007). The aim of this paper is to propose a new geosite assessment model (in further reading GAM), created by looking on the existing ones (Pralong 2005, Reynard et al. 2008, Pereira et al. 2007, Zouros 2007) which are here integrated into one manifold and for the purpose of this study applied on geosites of the Fruška Gora mountain in the Vojvodina region, north Serbia.

\section{Regional settings and geosites inventory}

Fruška Gora Mountain is situated at the confluence of the Danube and Sava Rivers, in Autonomous Province of Vojvodina, northern Serbia, between $45^{\circ} 00^{\prime}$ and $45^{\circ} 15^{\prime}$ north latitude and $16^{\circ} 37^{\prime}$ and $18^{\circ} 01^{\prime}$ north longitude (Figure 1). Although there are only a few peaks higher than 500 meters (highest peak, Crveni Čot at 539 meters), it represents a dominant orographic complex in the mostly plain and monotonous landscape of the Vojvodina region. Besides its geomorphologic significance this mountain represents the largest formation of geological and pedological diversity in the Pannonian area of Serbia. Furthermore, this relatively small region reflects a very complicated geological evolution that formed a unique tectonic, lithological and stratigraphic mosaic (Marković 2007b).

For the purpose of this research the inventory of geosites at Fruška Gora Mountain, determined by Marković et al. (2001), was used. These authors identified 14 geosites in situ according to their scientific, educational and aesthetic value, current condition and accessibility. The complete list of these geosites is presented in Table 1. Ex situ sites were excluded from this paper because their characteristics could not be assessed by the selected indicators and thus could not be evaluated properly by GAM. 


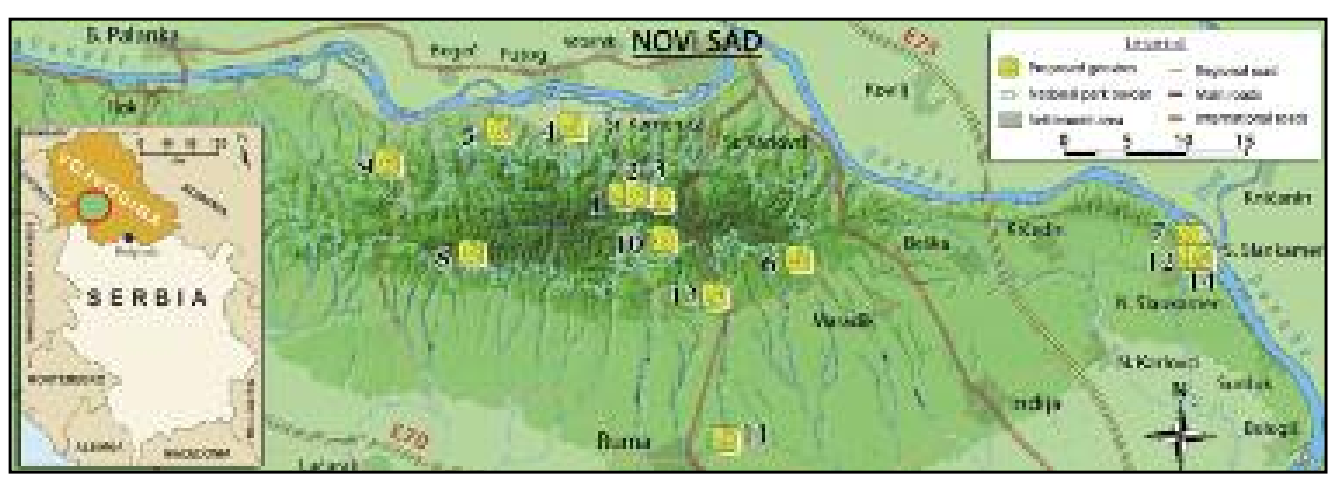

Figure 1: Location of Fruška Gora Mountain with disposition of proposed geosites (Marković, 2007b, modified).

Table 1: Preliminary list of geosites of Fruška Gora Mountain with description (Marković etal., 2001).

\begin{tabular}{|c|c|c|}
\hline No. & Geosite Name and Label & Description \\
\hline 1 & $\begin{array}{l}\text { The site of volcanic tuff »Galerija“ } \\
\text { near Rakovac village - GS }\end{array}$ & $\begin{array}{l}\text { Tuff horizon ( } 8 \mathrm{~m} \text { thick) interstratified between Miocene - Tortonian layers. The monument } \\
\text { of Nature from } 1982 \text { (Knežević, 1998). }\end{array}$ \\
\hline 2 & $\begin{array}{l}\text { Trachyte Quarry »Kišnjeva } \\
\text { glava« - GS }\end{array}$ & $\begin{array}{l}\text { Trachyte dyke injected into Cretaceous formations of sandstone and flysch. The hight } \\
\text { of steep slopes up to } 80 \mathrm{~m} \text { (Petković etal., 1976). }\end{array}$ \\
\hline 3 & $\begin{array}{l}\text { Trachyte Quarry »Srebro« near } \\
\text { Ledinci village - } \mathrm{GS}_{3}\end{array}$ & $\begin{array}{l}\text { Abandoned quarry with lake of exceptional aesthetic values. Steep slopes high up to } 110 \mathrm{~m} \text {. } \\
\text { Very good display of geo and biodiversity (Petković et al., 1976). }\end{array}$ \\
\hline 4 & $\begin{array}{l}\text { Palaeontological site of Miocene } \\
\text { marine fossils- »Filijala« near } \\
\text { Beočin village }-\mathrm{GS}_{4}\end{array}$ & $\begin{array}{l}\text { Upper Miocen-Pannonian sediments with rich presence of caspibrackish water fauna. } \\
\text { This site is considered as important checkpoint for sediment age determination in the region } \\
\text { of ancient Tethys Ocean as a parastratotype (Knežević, 1998). }\end{array}$ \\
\hline 5 & $\begin{array}{l}\text { Palaeontological site of Cretaceous } \\
\text { marine fossils in Čerević village - GS }\end{array}$ & $\begin{array}{l}\text { The most complete succession of the Upper- Cretaceous sediments. Fossil remains } \\
\text { of Orbitoides, Loftusias, corrals, worms, Brachiopods, Gastropods and Lamelibranhiats } \\
\text { (Petković etal., 1976). }\end{array}$ \\
\hline 6 & $\begin{array}{l}\text { Palaeontological locality of the mio- } \\
\text {-pliocenic fossils-»Grgeteg } «-\mathrm{GS}_{6}\end{array}$ & $\begin{array}{l}\text { The sediments of Sarmat, Upper Pontian and Pannonian age with rich caspibrachish water } \\
\text { mollusk fauna. More than } 40 \text { species were extracted and determined from the exposed site } \\
\text { (Knežević, 1998; Petković etal., 1976). }\end{array}$ \\
\hline 7 & $\begin{array}{l}\text { The structural palaeontological site } \\
\text { of Neogene gastropod marine fossils } \\
\text { near Stari Slankamen village }-\mathrm{GS}_{7}\end{array}$ & $\begin{array}{l}\text { Pannonian age sediments in discordant and transgressive position overlaying Badenian } \\
\text { age limestones with numerous fossil marine gastropods (Knežević, 1998). }\end{array}$ \\
\hline 8 & »Grgurevačka« cave $-\mathrm{GS}_{8}$ & $\begin{array}{l}\text { A unique karst underground geomorphological object in Vojvodina, northern Serbia } \\
\text { (Petrović, 1966) }\end{array}$ \\
\hline 9 & $\begin{array}{l}\text { A gorge-like part of Almaš } \\
\text { brook valley }-\mathrm{GS}_{9}\end{array}$ & $\begin{array}{l}\text { Composite valley in the lower course of brook (of around } 100 \mathrm{~m} \text { ) sediments with small } \\
\text { waterfalls formed in loess sediments (Miljković etal., 1998) }\end{array}$ \\
\hline$\overline{10}$ & Vrdnik mine $-\mathrm{GS}_{10}$ & $\begin{array}{l}\text { Abandoned coal mine with rich geological depository revealed in } 26 \text { underground mine } \\
\text { shafts up to } 280 \mathrm{~m} \text { of depth (Vasiljević and Marković, 1999). }\end{array}$ \\
\hline 11 & $\begin{array}{l}\text { Loess section } \\
\text { (»Ruma« brickyard) - } \mathrm{GS}_{11}\end{array}$ & $\begin{array}{l}\text { Detailed evidence of paleogeographic events during the last } 450000 \text { years. Fossil } \\
\text { remains of the large Pleistocene mammals: Mamuthus primigenius and Ursus deningeri } \\
\text { (Marković etal., 2004; 2006). }\end{array}$ \\
\hline 12 & $\begin{array}{l}\text { Loess profile "Surduk« in the gully } \\
\text { between Novi and Stari Slankamen } \\
\text { villages }-\mathrm{GS}_{12}\end{array}$ & $\begin{array}{l}\text { Currently the only law protected loess exposure in Serbia with fossil palaeosols } \\
\text { (Marković, 2000). }\end{array}$ \\
\hline 13 & Loess section in »|rig « $-\mathrm{GS}_{13}$ & The most northern profile with temperate and arid like terrestrial fossil malacofauna which \\
\hline 14 & $\begin{array}{l}\text { Loess profile „Čot« in Stari } \\
\text { Slankamen village }-\mathrm{GS}_{14}\end{array}$ & $\begin{array}{l}\text { indicates the existence of dry and warm glacial palaeoclimate (Marković, 2007c). } \\
40 \mathrm{~m} \text { tick section with } 10 \text { palaeosols (contains valuable paleoclimatic and paleoenvironmental } \\
\text { records of the Middle and Late Pleistocene) (Marković, submitted). }\end{array}$ \\
\hline
\end{tabular}




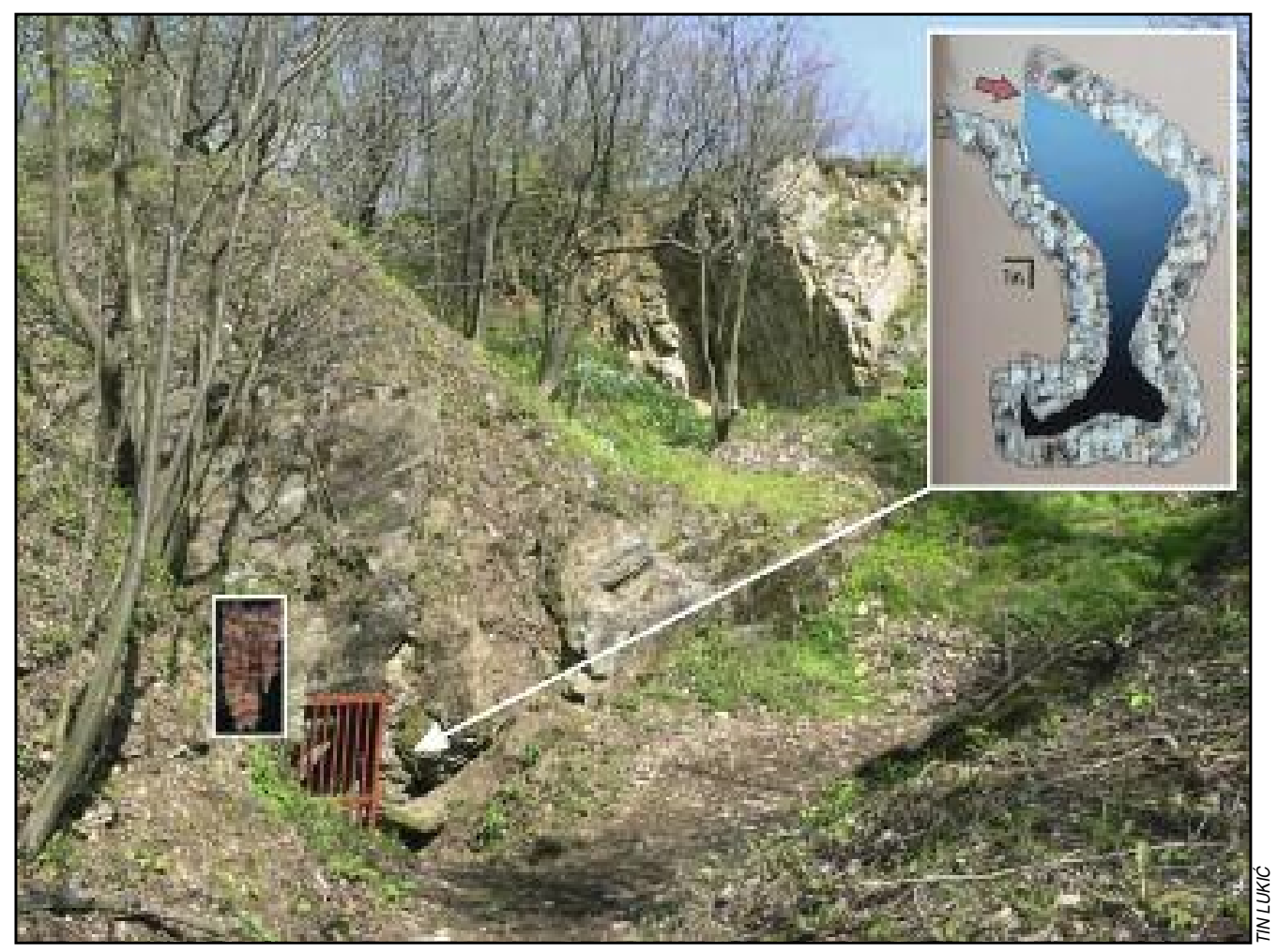

Figure 2: Grgurevac cave - unique karst underground geomorphological object in Vojvodina, northern Serbia.

Fruška Gora was proclaimed a National Park in 1960 with 25,525 ha of protected area due to its rich, rare and endangered biodiversity. Flora is presented by 1,454 species (Butorac 2007), while fauna refers primarily to ornithofauna with more than 200 species (Habijan-Mikeš 2007). Additionally, within the Park and wider area of Fruška Gora Mountain, there are numerous historical and cultural monuments with almost 20 orthodox monasteries hidden in the woods which earned this destination the epithet 'the Holy Mountain' apropos Serbian Atos (Davidov 2007).

Although some of the proposed geosites are within the National Park and thus officially under national concern, these sites do not have an adequate level of protection. Even worse, several sites (e.g. loess sections in Ruma and Irig, palaeontological site »Filijala «) are in the possession of commercial companies and exploited as construction resources (Vasiljević et al. in press). On the other hand, some features are less well known to the public, in remote or inaccessible areas, or perfectly hidden by nature and therefore still intact and preserved.

\section{Methodology}

The evaluation of geosites has been developing since the 1990s in terms of their interpretative potential and provision (Hose 1997, 2000). Three main physical domains (Reynard 2008) have also been recognised from the 1990s onwards: within the context of Environmental Impact Assessment (EIA) procedures (Rivas et al. 1997, Cendrero and Panizza 1999); for the elaboration of geographic knowledge on the geomorphological heritage in the context of land planning (Stürm 1994, Grandgirard 1999); and finally, and more recently, in the context of the promotion of the geomorphological heritage (geotourism, cultural heritage in a broad sense; see Panizza and Piacente 2003). Very useful comparison of four major assessment 
models (respectively: Reynard etal. 2007, Pereira etal. 2007, Pralong 2005 and Serrano and Gonzales-Trueba 2005) was given by Erhartič 2010 who also claims that contemporary models should reduce the subjective factor with the assistance of numerical evaluation which could raise the level objectiveness and provide more effective geosite comparison in general.

In order to create GAM, various relevant publications on these issues were consulted. For over a decade numerous papers were written concerning the evaluation of scientific, aesthetic and other values of geosites (e.g. Hose 1997, Pralong 2005, Reynard et al. 2008, Pereira et al. 2007, Zouros 2007, etc). According to Reynard etal. (2007) most of them could be divided in several groups, due to their scopes and aims. Consequently, one group regards preferentially environmental impact assessment (EIA) and land-use inventories evaluating only scientific values (e.g. Grandgirard 1999, Rivas et al. 1997, Bonachea et al. 2005, Coratza and Giusti 2005), while other evaluates not only the scientific quality of the sites, but also their additional values, such as ecological, aesthetic, cultural and economic (Reynard et al. 2007). Methods of the most recent group of research (e.g., Bruschi and Cendrero 2005, Serrano and Gonzales-Trueba 2005, Pralong 2005, Pereira et al. 2007), besides the quality of the sites, also evaluate their use or potential for use, as they take into consideration accessibility, visibility, present use of the geomorphological interest, present use of other natural and cultural interests, legal protection and equipment and support services, which are very important for tourism development. Pralong (2005) has developed a specific method for the assessment of the tourist quality of geomorphosites and their use by the tourism sector as he evaluates cultural and economic potentials of geosites.

The Geosite Assessment Model (GAM) was created according to several existing evaluation methods and most of the criteria proposed for the numerical assessment were taken from extant literature on the field. The complete structure of GAM is presented in Table 2. With the slight modification of existing models (e.g. Reynard et al. 2007, Pereira et al. 2007) that specify two groups of indicators - scientific and additional, GAM proposes main and additional values.

The first group, main values, comprises three indicators: scientific/educational, scenic/aesthetical and protection values. The first indicator in main values group is scientific and educational value (VSE) as suggested by Zouros (2007) with subindicators also proposed by Reynard et al. (2007), Pereira et al. (2007) and Pralong (2005), but with additional component »level of interpretation« as key element for understanding and explanation to wider audience and non-specialists. In contrast to before mentioned references, scenic and aesthetic values (VSA) are by GAM identified as main values, as they are relatively constant in time and not significantly human-influenced in general. This indicator was mostly created after Pralong (2005) with addition of »environmental fitting of site«, e.g. does certain manmade outcrop fit to its natural surroundings. Opposite to some previous models (e.g. Legal protection and use limitations, Pereira et al. 2007; Threats/Endangerment level, Reynard 2007; Potential threats \& protection needs, legal protection and vulnerability, Zouros 2007), protection (VPr) is here presented as indicator of main values, it should be essential activity before any promotional or tourism development in general.

The second indicator group of the geosite assessment model, additional values, is further divided in to two indicators, functional and touristic values, as presented in Table 2. Some authors previously proposed some functional elements such as (e.g. Accessibility, Pralong 2005, Pereira et al. 2007 Zouros 2007), but for the purpose of this paper and model Functional value (VFn), was further developed and it consists of six elements. New elements that were added are additional natural values, additional anthropogenic values, vicinity of emissive centers, vicinity of important road network and additional functional values. Purpose of these elements is not tourism development and they do not directly contribute to tourism, but are essential.

The third and last indicator, Tourism values (VTr), evaluates the current state of (geo) tourism services and facilities. Several authors proposed some elements of the tourism values - e.g. Equipment and support services as a part of Use value (Pereira et al. 2007), management measures (Reynard 2007), economic potential as a potential for use indicator (Zouros 2007), annual number of visitors and attraction as part of economic values (Pralong 2005). In contrast to the previous models, GAM offers tourism values as independent indicator with nine subindicators (see Table 2).

In total sum, there are 12 subindicators of Main Values, and 15 subindicators of Additional Values which are graded from 0 to 1 (see Table 2 ) that define GAM as a simple equation:

- GAM = Main Values (VSE + VSA + VPr) + Additional Values (VFn + VTr) 
Table 2: The structure of geosite assessment model (GAM).

\begin{tabular}{|c|c|}
\hline Indicators/Subindicators & Description \\
\hline \multicolumn{2}{|l|}{ Scientific/Educational value (VSE) } \\
\hline Rarity & Number of closest identical sites \\
\hline Representativeness & $\begin{array}{l}\text { Didactic and exemplary characteristics of the site due to its own quality } \\
\text { and generalconfiguration (Perreira, 2007) }\end{array}$ \\
\hline Knowledge on geoscientific issues & Number of written papers in acknowledged journals, thesis, presentations and other publications \\
\hline Level of interpretation & $\begin{array}{l}\text { Level of interpretive possibilities on geological and geomorphologic processes, } \\
\text { phenomena and shapes and level of scientific knowledge. }\end{array}$ \\
\hline
\end{tabular}

\section{Scenic/Aesthetic (VSA)}

Viewpoints

Number of viewpoints accessible by a pedestrian pathway. Each must present a particular angle of view and be situated less than $1 \mathrm{~km}$ from the site.

Surface

Whole surface of the site. Each site is considered in quantitative relation to other sites.

Surrounding landscape and nature

Environmental fitting of sites

Panoramic view quality, presence of water and vegetation, absence of human-induced deterioration, vicinity of urban area, etc.

Level of contrast to the nature, contrast of colors, appearance of shapes, etc.

\section{Protection (VPr)}

Current condition

Protection level

Vulnerability

Suitable number of visitors
Current state of geosite.

Protection by local or regional groups, national government, international organizations, etc. Vulnerability level of geosite

\section{Functional (VFn)}

Accessibility

Additional natural values

Additional anthropogenic values

Vicinity of emissive centers

Vicinity of important road network

Additional functional values

\section{Touristic values (VTr)}

Promotion

Organized visits

Vicinity of visitors center

Interpretative panels

Number of visitors

Tourism infrastructure

Tour guide service

Hostelry service

Restaurant service
Proposed number of visitors on the site at the same time, according to surface area, vulnerability and current state of geosite.

Possibilities of approaching to the site
Number of additional natural values in the in radius of $5 \mathrm{~km}$ (geosites also included).

Number of additional anthropogenic values in the in radius of $5 \mathrm{~km}$.

Closeness of emissive centers.

Closeness of important road networks in the in radius of $20 \mathrm{~km}$.

Parking lots, gas stations, mechanics, etc.

Level and number of promotional resources.

Annual number of organized visits to the geosite.

Closeness of visitor center to the geosite.

Interpretative characteristics of text and graphics, material quality, size, fitting to surroundings, etc.

Annual number of visitors

Level of additional infrastructure for tourist (pedestrian pathways, resting places, garbage cans, toilets, wellsprings etc.).

If exists, expertise level, knowledge of foreign language(s), interpretative skills, etc

Hostelry service close to geosite.

Restaurant service close to geosite. 


\begin{tabular}{|c|c|c|c|c|}
\hline \multicolumn{5}{|c|}{ Grades (0-1) } \\
\hline 0 & 0.25 & 0.5 & 0.75 & 1 \\
\hline Common & Regional & National & International & The only occurrence \\
\hline None & Low & Moderate & High & Utmost \\
\hline None & Local publications & Regional publications & National publications & International publications \\
\hline None & $\begin{array}{c}\text { Moderate level of } \\
\text { processes but hard to } \\
\text { explain to non experts), }\end{array}$ & $\begin{array}{l}\text { Good example } \\
\text { of processes but hard to } \\
\text { explain to non experts }\end{array}$ & $\begin{array}{c}\text { Moderate level of } \\
\text { processes but easy to } \\
\text { explain to common visitor }\end{array}$ & $\begin{array}{l}\text { Good example of } \\
\text { processes and easy to } \\
\text { explain to common visitor }\end{array}$ \\
\hline None & 1 & 2 to 3 & 4 to 6 & More than 6 \\
\hline Small & - & Medium & - & Large \\
\hline- & Low & Medium & High & Utmost \\
\hline Unfitting & - & Neutral & - & Fitting \\
\hline
\end{tabular}

\begin{tabular}{|c|c|c|c|c|}
\hline $\begin{array}{l}\text { Totally damaged } \\
\text { (as a result of human } \\
\text { activities) }\end{array}$ & $\begin{array}{c}\text { Highly damaged } \\
\text { (as a result of natural } \\
\text { processes) }\end{array}$ & $\begin{array}{l}\text { Medium damaged } \\
\text { (with essential } \\
\text { geomorphologic } \\
\text { features preserved) }\end{array}$ & Slightly damaged & No damage \\
\hline None & Local & Regional & National & International \\
\hline $\begin{array}{l}\text { Irreversible (with } \\
\text { possibility of total loss) }\end{array}$ & $\begin{array}{c}\text { High (could } \\
\text { be easily damaged) }\end{array}$ & $\begin{array}{c}\text { Medium (could } \\
\text { be damaged by natural } \\
\text { processes or human } \\
\text { activities) }\end{array}$ & $\begin{array}{l}\text { Low (could be damaged } \\
\text { only by human activities) }\end{array}$ & None \\
\hline 0 & 0 to 10 & 10 to 20 & 20 to 50 & More than 50 \\
\hline Inaccessible & $\begin{array}{l}\text { Low (on foot with } \\
\text { special equipment and } \\
\text { expert guide tours) }\end{array}$ & $\begin{array}{l}\text { Medium (by bicycle } \\
\text { and other means of } \\
\text { man-powered transport) }\end{array}$ & High (by car) & Utmost (by bus) \\
\hline None & 1 & 2 to 3 & 4 to 6 & More than 6 \\
\hline None & 1 & 2 to 3 & 4 to 6 & More than 6 \\
\hline More than $100 \mathrm{~km}$ & 100 to $50 \mathrm{~km}$ & 50 to $25 \mathrm{~km}$ & 25 to $5 \mathrm{~km}$ & Less than $5 \mathrm{~km}$ \\
\hline None & Local & Regional & National & International \\
\hline None & Low & Medium & High & Utmost \\
\hline None & Local & Regional & National & International \\
\hline None & Less than 12 per year & 12 to 24 per year & 24 to 48 per year & More than 48 per year \\
\hline More than $50 \mathrm{~km}$ & 50 to $20 \mathrm{~km}$ & 20 to $5 \mathrm{~km}$ & 5 to $1 \mathrm{~km}$ & Less than $1 \mathrm{~km}$ \\
\hline None & Low quality & Medium quality & High quality & Utmost quality \\
\hline None & $\begin{array}{c}\text { Low } \\
\text { (less than 5000) }\end{array}$ & $\begin{array}{c}\text { Medium } \\
\text { (5001 to } 10.000)\end{array}$ & $\begin{array}{c}\text { High } \\
\text { (10.001 to } 100.000)\end{array}$ & $\begin{array}{l}\text { Utmost } \\
\text { (more than 100.000) }\end{array}$ \\
\hline None & Low & Medium & High & Utmost \\
\hline None & Low & Medium & High & Utmost \\
\hline More than $50 \mathrm{~km}$ & $25-50 \mathrm{~km}$ & $10-25 \mathrm{~km}$ & $5-10 \mathrm{~km}$ & Less than $5 \mathrm{~km}$ \\
\hline More than $25 \mathrm{~km}$ & $10-25 \mathrm{~km}$ & $10-5 \mathrm{~km}$ & $1-5 \mathrm{~km}$ & Less than $1 \mathrm{~km}$ \\
\hline
\end{tabular}




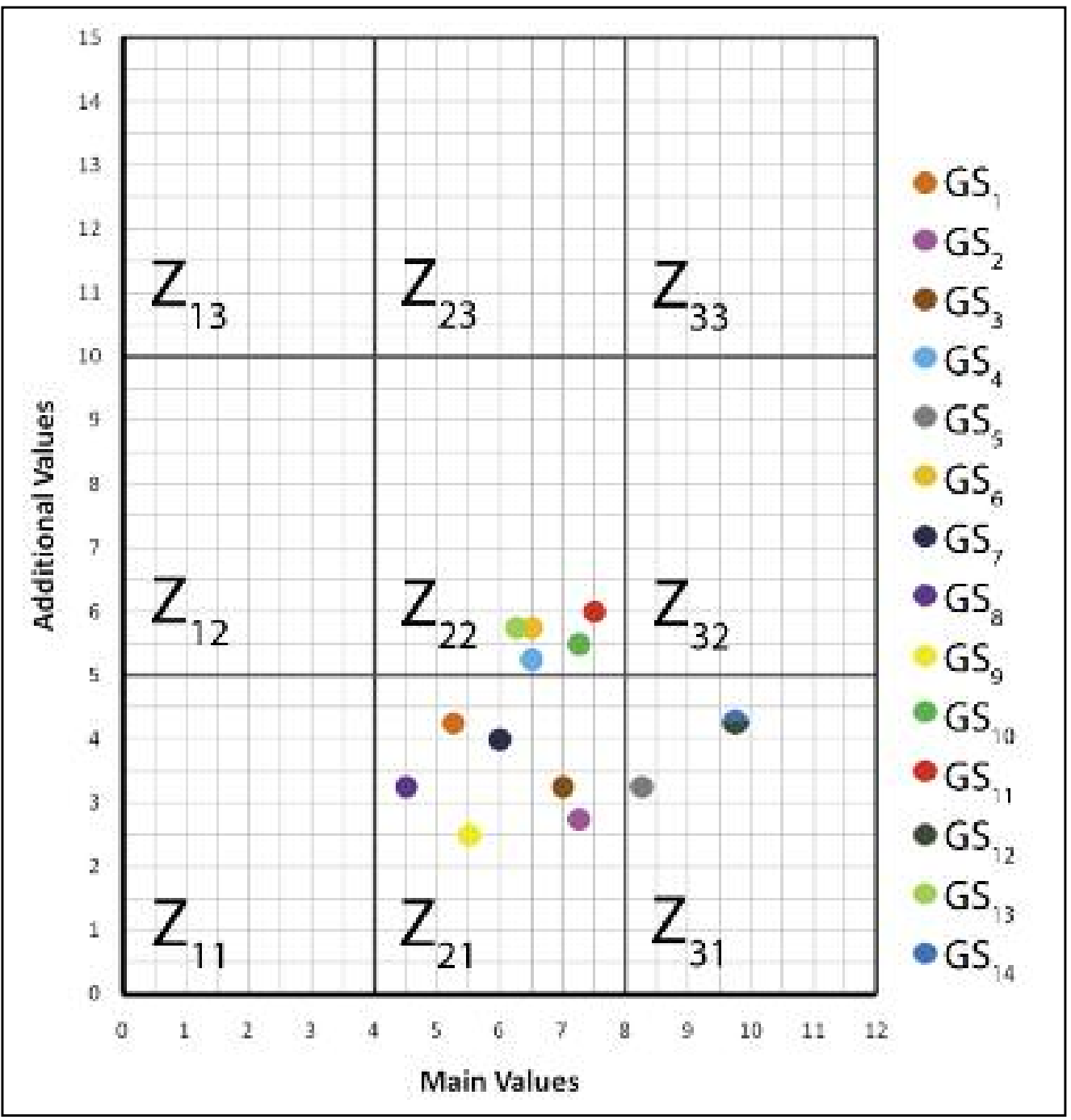

Figure 3: Disposition of geosites to certain fields according to GAM.

Based on the results of the assessment, a matrix of main and additional values could be created (Figure 3), where these values are presented via $\mathrm{X}$ and $\mathrm{Y}$ axes respectively. The matrix is divided into nine fields (zones) that are indicated by $\mathrm{Z}(\mathrm{i}, \mathrm{j})(\mathrm{i}, \mathrm{j}=1,2,3)$ based on the grade they received in the previous evaluation process. Major gridlines that create fields, for $\mathrm{X}$ axe have value of 4 and for $\mathrm{Y}$ axe of 5 units. This means that, for example, if sum of Main Values is 7 and of additional values is 4, the geosite would be in the field Z21 which indicates moderate level of Main Values and low level of Additional Values.

During the quantification phase, the importance of sites is determined by attribution of values to predetermined criteria. According to certain assessment, each geosite can be plotted in the field of the matrix with regard to its position in relation to each continuum (main and additional values) as indicated in Figure 3.

It then could be linked to an appropriate overall tourism development, market appeal and conservation management policy which could benefit its future. When evaluating a geosite, managers need to asses current condition. As mentioned, there are five subindicators that evaluate the geosite and its main and 
additional values. After ratings are done, every geosite is put in one field or cell of the matrix. For example, geosites that fit in cell Z31 and Z32 have high scientific, aesthetic and protection values, but low developed tourist and functional sector. So managers have to promote, plan and enhance these assets, while not degrading the first one. On the other side, geosites that fit in Z11 and Z12 cell have low main values and also low additional values. In this case there are two scenarios: the first one is that the geosite has no main values, and because of that additional values are also low; the second scenario is where the geosite is not fully researched and because of that is not protected, which implies that there is no need for additional values. Geosites that fit in Z33 and Z23 have high ratings in main and additional values. On these sites managers should measure the impact of tourism and threats; a solution for this problem is the constant monitoring of proposed subindicators.

\section{Application of GAM to Stari Slankamen loess geosite}

In order to thoroughly elucidate utilization of GAM, the proposed method will be applied to loess profile Čot near Stari Slankamen (Table 1 (GS14), Figure 4). Accordingly, the proposed methodology is clarified in some detail.

The first group of main indicators, scientific and educational (VSE) values, shows highest values (Grade 1) of subindicators rarity and representativeness as this site represents one of the most complete palaeoclimatic and palaeoenvironmental archive on European land (Marković et al., 2007a). Also, numerous scientific papers regarding this site, published in acknowledged international journals (e.g. Marković et al. 2007a, 2008,2009 , submitted), also bring the highest grade for knowledge on geoscientific issues. All this resulted in the highest interpretation level as it is concluded that the Stari Slankamen loess profile represents an excellent example of palaeoclimatic and palaeoenvironmental records of the Middle and Late Pleistocene

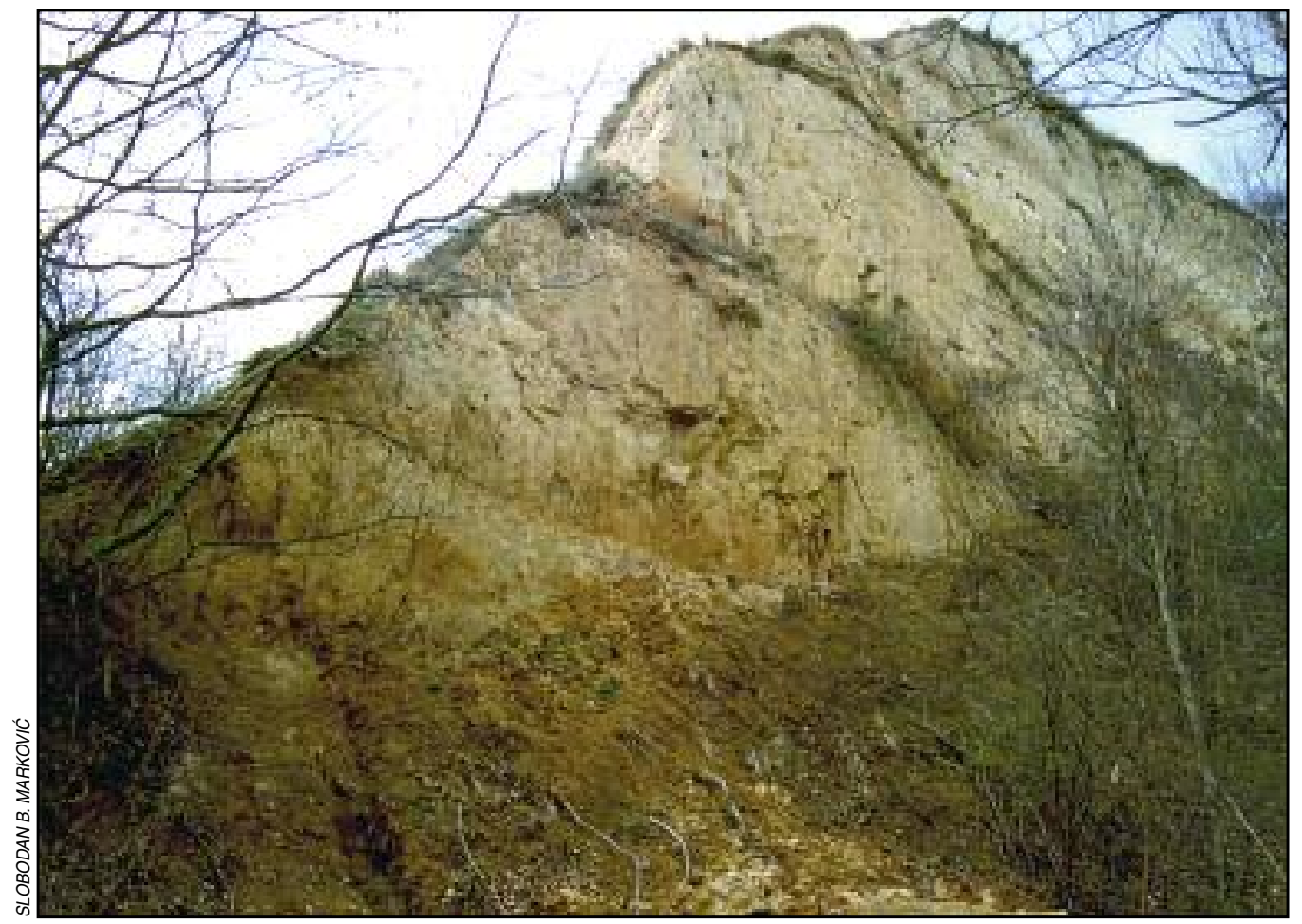

Figure 4: Profile Čot near Stari Slankamen village, the most significant loess section in the Vojvodina region. 
that could provide simple and interesting stories to common tourists who are non-specialists or casual geotourists (Hose 2005b).

Apart from the above mentioned values, the Stari Slankamen site also possesses notable scenia (VSA) that can be observed from three different viewpoints (0.5). Furthermore, the site is situated and well fitted on the far slopes of Fruška Gora Mountain, with exquisite natural surroundings and a view at confluence of Danube and Tisza rivers, river islands and wetlands on the opposite bank. This earned high grades for surrounding landscape and nature (0.75), its surface (1) in comparison to other sites and environmental fitting of sites (1).

As formerly stated, the last group of main values is based on level of protection (VPr) and human involvement. The Stari Slankamen loess profile, although not officially protected (Grade 0 ) is only slightly damaged due to the natural processes (0.75). Damage to this site could occur only in a long time due to the natural processes $(0.75)$ and due to its large surface area it can withstand more than 50 visitors at once (1).

Opposite to main, subindicators of additional values have mostly medium or low values. Functional indicators (VFn), such as accessibility, vicinity of important road network or additional functional values have average grade (0.5) as the site is accessible only on foot and bicycle, the regional road is in its vicinity and the mediocre level of additional functional values - no proper parking lot, but it has all the other needed functional commodities. Additional natural values and anthropogenic values also earned medium grade for the Danube and Tisza rivers vicinity, loess profile "Surduk « in the gully between Novi and Stari Slankamen villages, mineral spring »Slanka«, remains of Roman fortification Acuminicum, Stari Slankamen spa, oldest one in the Vojvodina region and Ottoman bath house, etc. As the closest greater emissive (Novi Sad and Belgrade) are more than $50 \mathrm{~km}$ from the site, this subindicator is graded by 0.25 .

As geotourism is a still only theoretical phenomenon in Serbia, (geo) touristic (VTr) characteristics have the lowest values of all indicators as there are no organized visits and visitors at all, nor tour guide service (grade 0), with low level of interpretative panel, tourism infrastructure, hostelry and restaurant service (grade 0.25 ).

Based on the sum of grades the Stari Slankamen loess profile has high level of main values (9.5 of 12) and low level of additional (4.25 of 15). The overall grade puts the Stari Slankamen loess profile in the Z31 cell which is shown in Figure 3. This indicates that further attention towards creating tourism attractive geosite should be directed to tourism infrastructure and services. Although in good condition, the protection status of this site should never be neglected.

\section{Results and discussion}

By following the evaluation methodology of the Stari Slankamen site, all fourteen proposed geosites at Fruška Gora Mountain have been assessed (see Table 3). A more visual approach to the evaluation results can be presented as a matrix (see Figure 3 ) in which every site is presented by dots with their pertinence to the relevant field.

The matrix evidently indicates that six sites fit in the Z21 field, five of them in Z22 field and three in Z31 field. These results show that the sites are graded with high (21\%) and medium (79\%) levels of the main values, with no single site in the low level, which leads to the conclusion that Fruška Gora Mountain has adequate levels of natural resources for geotourism development. However, the analysis also shows that nine geosites (64\%) have low additional values, with none belonging to the high level of this group. This implies that there is an urgent need for the more rapid, though sustainable, development of tourism infrastructure and services. The presence of the National Park should hasten this process as certain facilities already exist and could regain their functionality with slight modifications. With the development of additional values, the main values would also advance through public awareness and appreciation of the geosites. This would lead to a much thorough investigations of this destination and, with new discoveries, the protection and thus promotion of these locations would bring more consideration to the additional values. As is perhaps obvious, the development of both main and additional values is a closed circle where affecting one influences the other.

The proposed geosite assessment model is only a preliminary one, and the next step should be the evaluation of weighting criteria. Tourists, conservation managers and tourism managers should be inter- 
Table 3: Overall ranking of Fruška gora mountain geosites using GAM.

\begin{tabular}{|c|c|c|c|c|}
\hline \multirow[t]{2}{*}{ Geosite Label } & \multicolumn{4}{|c|}{ Values } \\
\hline & $\begin{array}{c}\text { Main } \\
V S E+V S A+V P r\end{array}$ & $\begin{array}{l}\text { Additional } \\
\text { VFn+VTr }\end{array}$ & Overall & Field \\
\hline $\mathrm{GS}_{1}$ & $2+1.25+2$ & $2.75+1.5$ & 9.5 & $Z_{21}$ \\
\hline $\mathrm{GS}_{2}$ & $2.25+2.5+2.5$ & $2.25+0.5$ & 10 & $Z_{21}^{21}$ \\
\hline $\mathrm{GS}_{3}^{2}$ & $1.75+3.5+1.75$ & $3+0.25$ & 10.25 & $Z_{21}$ \\
\hline $\mathrm{GS}_{4}^{3}$ & $2.5+2.25+1.75$ & $3.25+2$ & 11.75 & $Z_{22}$ \\
\hline $\mathrm{GS}_{5}^{4}$ & $2.25+2.75+3.25$ & $2.25+1$ & 11.5 & $Z_{31}$ \\
\hline $\mathrm{GS}_{6}$ & $2.5+1.75+2.25$ & $3.75+2$ & 12.25 & $Z_{22}$ \\
\hline $\mathrm{GS}_{7}$ & $2.25+1.75+2$ & $3+1$ & 10 & $Z_{21}$ \\
\hline $\mathrm{GS}_{8}^{\prime}$ & $1+1.5+2$ & $1.75+1.5$ & 7.75 & $Z_{21}$ \\
\hline $\mathrm{GS}_{9}$ & $1.75+2.25+1.5$ & $1.75+0.75$ & 8 & $Z_{21}$ \\
\hline $\mathrm{GS}_{10}$ & $2.25+3+2$ & $4+1.5$ & 12.75 & $Z_{22}$ \\
\hline $\mathrm{GS}_{11}^{0}$ & $3.25+2.75+1.5$ & $4+2$ & 13.5 & $Z_{22}$ \\
\hline $\mathrm{GS}_{12}$ & $3.25+3.25+3.25$ & $2.75+1.5$ & 14 & $Z_{31}$ \\
\hline $\mathrm{GS}_{13}^{2}$ & $3.5+2.25+1.5$ & $4+1.75$ & 12 & $Z_{22}$ \\
\hline $\mathrm{GS}_{14}^{-}$ & $4+3.25+2.5$ & $2.75+1.5$ & 14 & $Z_{31}$ \\
\hline
\end{tabular}

viewed in order to assess the value of each indicator's elements, as the elements are of unequal importance with regard to tourism planning and management. For example, within the main values, interpretation level and rareness or representativeness of site, which are relatively constant in time (except if major discoveries occur), should be considered as more valuable than its surface or environmental fitting. Evidently, for the purpose of geotourism development, it is more important to form or improve guide services or interpretive panels (Figure 5) than to have the road network or some additional functional values developed. Consequently, this is why scientific/educational and protection values should be evaluated by experts

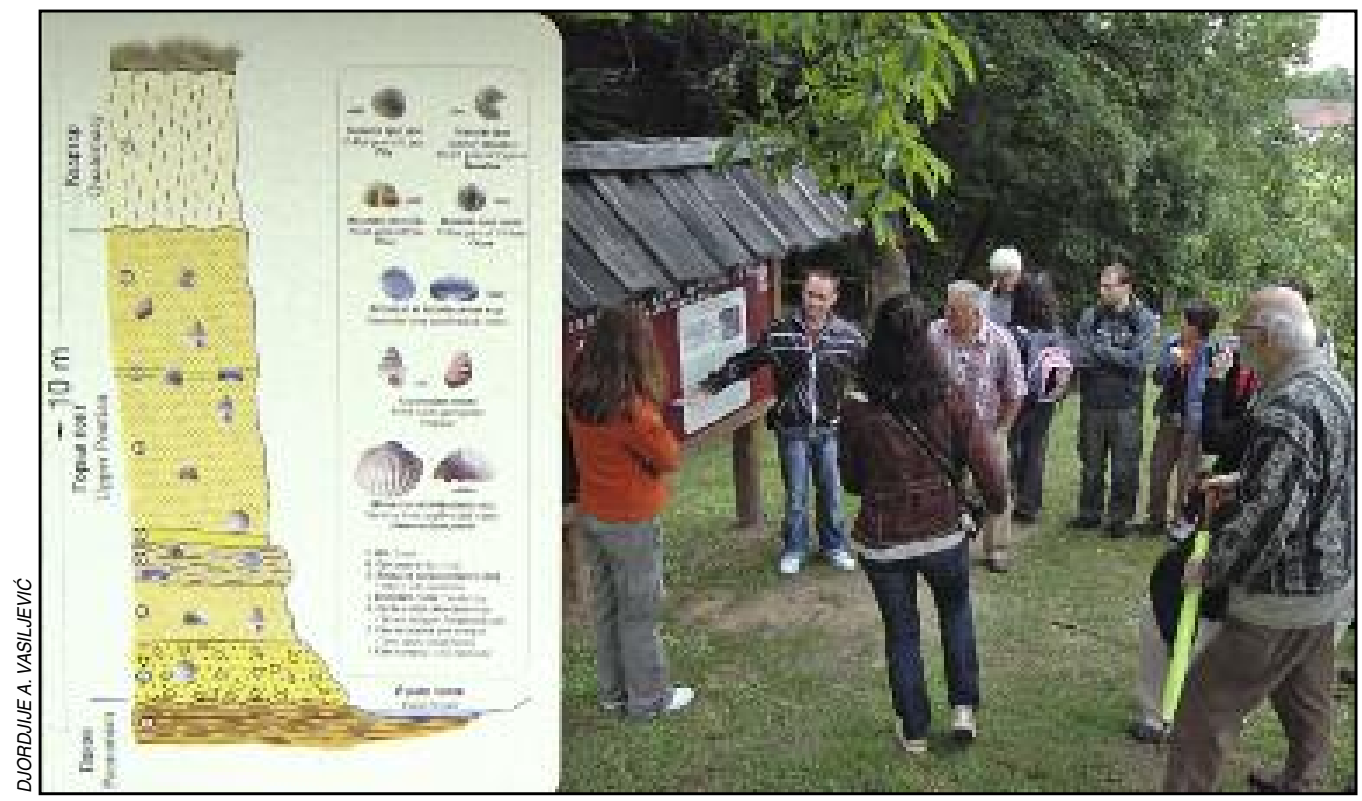

Figure 5: Geosite Grgeteg - palaeontological locality of the mio-pliocenic fossils, interpreted by T. Lukić during the Geotrends 2010 conference fieldtrip. 
and conservation managers, while aesthetic/scenic, functional and tourist values should be evaluated by visitors and their experiences. Based on the newly developed grading criteria of evaluated indicators, this model could then give clearer guidelines for recognising important geotourism destinations.

\section{Conclusion}

Nowadays, geosites have the potential to be acknowledged as both natural heritage and tourist resources with potential economic benefits (Hose 2005b), especially if located in protected areas, and when made readily physically and intellectually accessible to tourists (Hose 1996,2000). The results of the assessment indicate that the Fruška gora Mountain geosites have significant main values, but low additional values so they could be considered only as potential tourist attractions in terms of their scientific/educational values and aesthetic/scenic appeal, the latter has yet to be discovered and will require suitable tourism promotion. Further steps should involve improving and supplementing the essential geotouristic infrastructure (such as interpretive panels, marked paths, signs, etc.) and the promotion within the National Park itself and more globally (brochures, web promotion, fairs, seminars, etc.) its geosites. Also, there is an active initiative for proclaiming Fruška Gora a GEOpark, as it fulfils most of criteria (geodiversity, surface, etc.), but designation awaits the resolution of detailed political, managerial and planning issues. However, it is apparent that, in addition to all the other complementary natural and cultural values of this area, Fruška Gora Mountain provides a timely perspective on a potential sustainable (geo) touristic destination.

\section{Acknowledgement}

This work is supported by the Ministry of Science and Technological Development, Republic of Serbia (grant 176020).

\section{References}

Bonachea, J., Bruschi, V., Remondo, J., González-Díez, A., Salas, L., Bertens, J., Cendrero, A., Otero, C., Giusti, C., Fabbri, A., González-Lastra, J., Aramburu, J. 2005: An approach for quantifying geomorphological impacts for EIA of transportation infrastructures: a case study in northern Spain. Geomorphology 66. Amsterdam. DOI:10.1016/j.geomorph.2004.09.008

Boo, E. 1990: Ecotourism: the potentials and pitfalls. Washington.

Bruschi, V. M., Cendrero, A. 2005: Geosite evaluation. Can we measure intangible values?. Il Quaternario 18-1. Rome.

Butorac, B. 2007: Fruška gora: Prirodne odlike - biljni svet. Belgrade.

Cendrero, A., Panizza, M. 1999: Geomorphology and environmental impact assessment: an introduction. Supplementi di Geografia Fisica Dinamica Quaternaria 3-3. Turin.

Coratza, P., Giusti, C. 2005: Methodological proposal for the assessment of the scientific quality of geomorphosites. Il Quaternario 18-1. Rome.

Davidov, D. 2007: Fruška gora: Sveta srpska gora - Fruškogorska »Sveta Gora«. Belgrade.

Dixon, G. 1996: Geoconservation: an international review and strategy for Tasmania. Miscellaneous report parks \& wildlife service. Tasmania.

Erhartič, B. 2010. Geomorphosite assessment. Acta geographica Slovenica. Ljubljana. DOI: 10.3986/AGS49204

Erikstad, L. 2008: History of geoconservation in Europe. The history of geoconservation. London.

Fairbrother, N. 1970: New Lives, New Landscapes. London.

Grandgirard, V. 1999: L'évaluation des géotopes. Geologia Insubrica 4-1. Milano.

Gray, M. 2004: Geodiversity - valuing and conserving abiotic nature. London.

Habijan-Mikeš, V. 2007: Fruška gora: Prirodne odlike - životinjski svet. Belgrade.

Hose, T. A.: 1995. Selling the Story of Britain's Stone, Environmental Interpretation, 10-2. London.

Hose, T. A.: 1996. Geotourism: or can tourists become casual rockhounds? Geology on your Doorstep: The role of urban geology in earth heritage conservation. London. 
Hose, T. A.: 1997. Geotourism - selling the earth to Europe. Engineering geology and the environment. Amsterdam.

Hose, T. A. 2000: 'European Geotourism - geological interpretation and geoconservation promotion for tourists. Geological geritage: its conservation and management. Madrid.

Hose, T. A. 2003: Geotourism in England: a two-region case study analysis. Ph. D. thesis. University of Birmingham. Birmingham.

Hose, T. A. 2005a: Geo-tourism - appreciating the deep time of landscapes. Niche Tourism: contemporary issues, trends and cases. Oxford.

Hose, T. A. 2005b: Writ in Stone. Stone in Wales: Minerals, heritage and conservation. Cardiff.

Hose, T. A. 2007: Geotourism in Almeria province, southeast Spain. Tourism: an interdisciplinary journal. 55-3. Zagreb.

Hose, T. A. 2008: Towards a history of geotourism: definitions, antecedents and the future. The history of geoconservation. London.

Knežević, S. 1998: Geological neogene localities of fruška gora mountain. Protection of nature 48/49. Beograd.

Marković, S. B. 2000.: Paleogeografija kvartara na teritoriji Vojvodine. Ph. D. thesis. Instiute of Geography. Novi Sad.

Marković S. B., Mijović D., Jovanović M., Kovačev N. 2001: Geo-heritage sites of Fruška Gora Mountain. Protection of nature 53-1. Belgrade.

Marković, S. B., Kostić, N., Oches, E. A. 2004: Palaeosols in the Ruma loess section. Revista Mexicana de Ciencias Geologicas 21-1. Mexico City.

Marković, S. B., Oches, E., Sümegi, P., Jovanović, M., Gaudenyi, T. 2006: An introduction to the Upper and Middle Pleistocene loess-palaeosol sequences of Ruma section (Vojvodina, Serbia). Quaternary International 149. Oxford. DOI: 10.1016/j.quaint.2005.11.020

Marković, S. B., Hambach, U., Oches, E. A., McCoy, W. D., Zoeler, L., Jovanović, M. 2007a: 850 Millennia of paleoclimatic history recorded in the loess sequences of Vojvodina region, Serbia, Quaternary International 167/168. Oxford. DOI: 10.1016/j.quaint.2007.04.001

Marković, S. B. 2007b: Fruška gora: Fizičko-geografska svojstva. Beograd.

Marković, S. B., Oches, E. A., McCoy, W.D., Gaudenyi, T., Frechen, M. 2007c: Malacological and sedimentological evidence for »warm " glacial climate from the Irig loess sequence (Vojvodina, Serbia). Geophysics, Geochemistry and Geosystems 8. DOI: 10.1029/2006GC001565.

Marković, S. B., Bokhorst, M, Vandenberghe, J., Oches, E. A., Zöller, L., McCoy, W.D., Gaudenyi, T., Jovanović, M., Hambach, U., Machalett, B. 2008: Late Pleistocene loess-paleosol sequences in the Vojvodina region, North Serbia. Journal of Quaternary Science 23-1. Chichester. DOI:10.1002/jqs.1124

Marković, S. B., Smalley, I., Hambach, U., Antoine, P. 2009: Loess in the Danube region and surrounding loess provinces: The Marsigli memorial volume. Quaternary International 198, Oxford. DOI:10.1016/ j.quaint.2009.02.001

Marković, S. B., Hambach, U., Stevens, T., Kukla, G. J., Heller, F., William D. McCoy, W. D., Machalett, B., Oches, E. A., Buggle, B., Zöller, L. 2011. The last million years recorded at the Stari Slankamen loesspalaeosol sequence: revised chronostratigraphy and long-term environmental trends. Quaternary Science Reviews 30. Amsterdam. DOI: 10.1016/j.quascirev.2011.02.004

Miljković, Lj., Bogdanović, Ž., Krstić, N., Kovačev., N. 1998: Canyon Part of the Almaš Stream Valley Scientific Valorisation And Protection. In Serbian with English abstract. Protection of nature 48/49. Belgrade.

Novelli, M. 2005: Niche Tourism: contemporary issues, trends and cases. Oxford.

Page, S. J., Connell, J. 2007: Sustainable Tourism. London.

Panizza, M., Piacente, S. 2003: Geomorfologia culturale. Pitagora Editrice. Bologna.

Pereira, P., Pereira, D., Caetano Alves, M. I. 2007: Geomorphosite assessment in Montesinho Natural Park (Portugal). Geographica Helvetica 62. Basel.

Petković, K., Čičulić-Trifunović, M., Pašić, M., Rakić, M. 1976: Fruška Gora - monografski prikaz geološke građe i tektonskog sklopa. Matica srpska. Novi Sad.

Petrović, J. 1966: Grgurevačka pećina (speleobiološka istraživanja). Matica Srpska Proceedings for Natural Sciences 30. Novi Sad.

Pralong, J.P. 2005: A method for assessing the tourist potential and use of geomorphological sites. Géomorphologie. Relief, processus, environnement 3. Paris. 
Reynard, E., Fontana, G., Kozlik, L., Scapozza, C. 2007: A method for assessing »scientific« and »additional values« of geomorphosites. Geographica Helvetica 62-3. Basel.

Reynard, E. 2008: Scientific research and tourist promotion of geomorphological heritage. Geografia fisica e dinamica quaternaria 31-2. Turin.

Rivas V., Rix K., Francés, E., Cendrero, A., Brunsden, D. 1997: Geomorphological indicators for environmental impact assessment: consumable and non-consumable geomorphological resources. Geomorphology 18. Amsterdam. DOI: 10.1016/S0169-555X(96)00024-4

Serrano, E., González-Trueba, J. J. 2005: Assessment of geomorphosites in natural protected areas: the Picos de Europa National Park (Spain). Géomorphologie. Formes, processus, environnement 3. Paris.

Stürm, B. 1994. The geotope concept: geological nature conservation by town and country planning. Geological and Landscape Conservation. Malvern International Conference 1993. London.

Vasiljević, M., Marković, S. 1999: Rudnik mrkog uglja »Vrdnik« u Vrdniku. Faculty of Science, Institute of Geography. Novi Sad.

Vasiljević, Dj. A., Marković, S. B., Hose, T. A., Smalley, I., Basarin, B., Lazić, L., Jović, G. 2011. Geoconservation of Loess-Palaeosol Sequences in the Vojvodina Region: significant Geoheritage of Serbia. Quaternary International 240. Oxford. DOI: 10:10.1016/j.quaint.2010.07.008

Weiler, B., Hall, C. M. H. (eds.) 1992: Special Interest Tourism. Belhaven Press. London.

Zouros, N. C. 2007: Geomorphosite assessment and management in protected areas of Greece Case study of the Lesvos island - coastal geomorphosites. Geographica Helvetica 62-3. Basel. 